\title{
EHMTI-0297. Influences of psychiatric and behaviral factors on treatment effects in the school-age children with migraine
}

K Lee

From 4th European Headache and Migraine Trust International Congress: EHMTIC 2014

Copenhagen, Denmark. 18-21 September 2014

\section{Purpose}

School-aged children with severe migraine might need medication, and often accompanied by a psychiatric or behavioral problems. Thus, study for the effect of its problems on treatment of severe pediatric migraine is very important.

\section{Materials and methods}

Among the 197 school-aged children who were diagnosed as migraine by ICHD-3b, seventy-two patients who need prophylactic therapy were enrolled from January 2012 to December 2013. Secondary headaches and headaches with ADHD or require psychiatric treatments were excluded. Before treatment, all patients were checked by Childhood behavioral checklist (CBCL), Children's Anxiety Scale (CAS) and Children's Depression Inventory (CDI) for screening of behavioral and psychological problems, and administered with topiramate (25-50 $\mathrm{mg} \mathrm{hs}$ ) as a prophylactic medication. They were followed-up at intervals of 2-4 weeks and grouped as good responder (GR) and poor responder (PR).

\section{Results}

A total of 72 patients was M:F; 28:44, mean-age; $11.2 \pm 2.7$ years. GR (45 patients; $62.5 \%, \mathrm{M}: \mathrm{F} ; 18: 27$, age; $10.7 \pm 2.5$ ) and PR (27; 34.7\%, M:F; 10:17, age; $12.0 \pm 3.0)$ were no statistically different. Features of headache in GR (duration; about 6 mo, attack duration; $9 \mathrm{~h}$, frequencies; 12/mo) and PR (duration; about 12 mo, attack duration; $4 \mathrm{~h}$, frequencies; $16 / \mathrm{mo}$ ) had no significant difference. T-scores of GR and PR group were statistically different in total behavior problems, internalizing problems, depression/anxiety, social immaturity, attention problems of CBCL $(\mathrm{p}<0.01)$,

Pediatrics, Hallym University, Seoul, Korea but not different in factors of depression or anxiety in CAS and CDI.

\section{Conclusion}

Because behavioral factors affect the treatment children with migraine, it is important to selection of drugs or management of behavioral problems.

No conflict of interest.

Published: 18 September 2014

doi:10.1186/1129-2377-15-S1-G20

Cite this article as: Lee: EHMTI-0297. Influences of psychiatric and behaviral factors on treatment effects in the school-age children with migraine. The Journal of Headache and Pain 2014 15(Suppl 1):G20.

Submit your manuscript to a SpringerOpen ${ }^{\circ}$ journal and benefit from:

- Convenient online submission

- Rigorous peer review

- Immediate publication on acceptance

- Open access: articles freely available online

- High visibility within the field

- Retaining the copyright to your article

Submit your next manuscript at $\gg$ springeropen.com

(c) 2014 Lee; licensee Springer. This is an Open Access article distributed under the terms of the Creative Commons Attribution License (http://creativecommons.org/licenses/by/2.0), which permits unrestricted use, distribution, and reproduction in any medium, provided the original work is properly cited. 